\title{
Antimicrobial resistance of pathogenic bacteria isolated from minced meat in eastern Morocco
}

\author{
Kamal Belhaj ${ }^{1,2^{*}}$; Mohammed Khamri ${ }^{2,4}$; Abdelouadoud Omari ${ }^{1,2}$; Islam Abbadi ${ }^{2}$; Chaouki Belbachir ${ }^{2,3}$ \\ and Ahmed Elamrani ${ }^{1}$. \\ ${ }^{1}$ Department of Biology, Faculty of Sciences, University Mohammed First, BP-717, 60000 Oujda, Morocco; \\ ${ }^{2}$ Regional Laboratory of Analysis and Research, National Office for Food Safety, BP 73, 60000 Oujda, Morocco; \\ ${ }^{3}$ Laboratory of Applied Chemistry and Environment (LCAE), Associated CNRST 18-unit, Faculty of Science, University Mohammed; \\ ${ }^{4}$ Laboratory of Biochemistry, Faculty of Science, University Mohammed First, Oujda, Morocco.
}

Received date: 12 February 2019, Accepted date: 15 May 2019, Online date: 3 June 2019

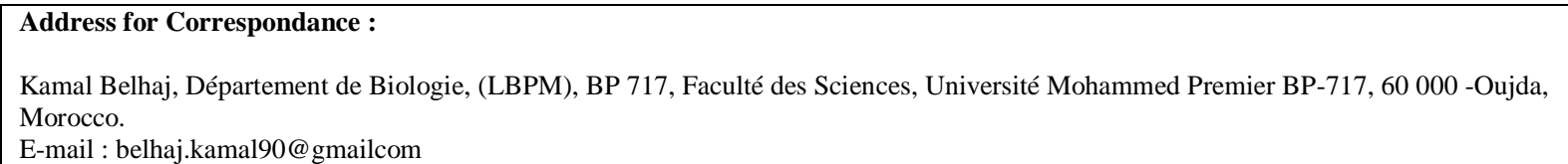

Copyright (C) 2019 by authors and American-Eurasian Network for Scientific Information.

This work is licensed under the Creative Commons Attribution International License (CC BY).

http://creativecommons.org/licenses/by/4.0/

\section{c) (i) Open Access}

\begin{abstract}
Currently, antibiotic resistance poses a serious threat as far as both animal and human therapies are concerned, and the monitoring of this problem plays an important role in sustainable development. It can affect anyone, anywhere. The aim of this is to evaluate the risk of microbial resistant to pathogenic bacteria isolated from ground meat marketed in the eastern region of Morocco. The enumeration of pathogenic Staphylococcus aureus (S. aureus), Escherichia coli (E. coli) and Salmonella spp. were carried out using ISO 6888-2, ISO16649-2 and ISO 6579 methods respectively. Indeed, the study of antibiotic resistance was carried out using the Mueller-Hinton medium according to the method described by French society of microbiology. A total of 51 samples of ground meat collected in eastern Moroccan butchers throughout March-April 20152017, were used to study the health risks of antibiotic resistance, 34 photogenic bacteria belonging to the following species Escherichia coli, salmonella and $S$. aureus were isolated. The antibiogram results showed that $100 \%$ of tested $E$. coli and salmonella strains are highly resistant to penicillin A, Nitrofurantoin, Erythromycin, Thiamphenicol, and Tetracycline. However, they are susceptible to Gentamicin and Colistin, and $100 \%$ of $E$. coli and $S$. aureus strains are susceptible to Cotrimoxazole. All tested bacterial strains (E. coli, Salmonella, and S. aureus) are susceptible to Gentamicin and have medium resistance to Streptomycin. These strong bacterial resistances largely explain the excessive and unsustainable uses of antibiotics in human and veterinary medicine, which calls for surveillance and vigilance against this global problem.
\end{abstract}

KEYWORDS

Minced meat, Antimicrobial resistance, photogenic bacteria, Eastern Morocco

\section{INTRODUCTION}

Antimicrobial resistance is not only a risk for animal health, but it is also a risk for humans through the direct or indirect transfer of pathogenic and multi-resistant bacteria [1-3]. The international scientific community is disturbed by the impotence in the face of increasingly dangerous antibiotic multi-resistant bacteria strains. Several therapeutic practices (preventive and curative) favor the selection of resistant bacteria, specifically in intensive livestock production [4]. The spread of antibiotic resistance due to the excessive or uncontrolled use of antibiotics as far as both humans and animals are concerned remains a major problem for the health of consumers. The use of antibiotics either to cure or to prevent illnesses when raising livestock enables 
Kamal Belhaj et al., 2019. Antimicrobial resistance of pathogenic bacteria isolated from minced meat in Eastern Morocco/ American-Eurasian Journal of Sustainable Agriculture. 13(2): 34-40. DOI: 10.22587/aejsa.2019.13.2.3

bacteria to develop antibiotic resistance. Sometimes, these bacteria aren't pathogenic, but they can transfer their resistance to other bacteria and become difficult to manage, it's a natural phenomenon in the world of bacteria [5-7].

Meat is considered as a food of choice due to its nutritional value, its richness in proteins, and the nature of those proteins make it necessary for a balanced diet. However, depending on its origins, meat can be contaminated by various antibiotic-resistant bacteria. In Morocco, red meat production is around 530000T [8]. Red meat consumption saw a light increase during the last 20 years, which went from $8.2 \mathrm{~kg}$ to 11.7 $\mathrm{kg} /$ individual/year. Currently, due to the consumption rate of red meat in Morocco, it is necessary to ensure its safety since its contamination can present a significant health risk.

The objective of this study is to evaluate the public health risk of antibiotic resistance of bacteria isolates from red meat sold in the Oriental Region of Morocco.

\section{Sampling site}

\section{MATERIAL AND METHODS}

The sampling was carried out from several markets and butcher shops of Oujda-Ahfir-Berkane-Zaiou cities during the years 2015 and 2017 between April-March. The analyses were conducted in the Laboratory of Analysis and Research of the National Office for Food Safety that works under quality assurance ISO 17025.

\section{Bacteria isolate collection}

The collection of bacterial species originating from food is carried out during routine microbiological analyses. 51 ground beef samples sold in Oriental Morocco were used in this study. The enumeration of pathogenic Staphylococcus and E. coli was carried out using the ISO 6888-2 [9] and ISO16649-2 [10] methods, respectively. The ISO 6579 method [11] was used for the detection of Salmonella spp. The results' interpretation was made according to the Order No 624-04 of 17 Safar 1425 (8 April 2004) related to the microbiological standards to be met by animal and animal-origin products, official journal No. 5214 of May 2, 2004 [12]. For comparative purposes, we also included the regulation applied in Luxembourg Table 1 [13].

The study of antibiotic resistance was carried out in 3 essential steps:

- Culture of the purified bacterial strains (originally found in ground beef) in Mueller-Hinton broth which is used as a non-selective medium to grow a very large number of bacteria of various origins by transferring them in the broth using sterile inoculating loops and incubating at $37^{\circ} \mathrm{C}$ for 24 hours.

- Swab inoculation of the bacterial strains grown in Mueller-Hinton broth on Mueller-Hinton agar and depositing of antibiotic discs, then incubation of agar plates at $37^{\circ} \mathrm{C}$ for 24 hours.

- Measurement of inhibition zones.

The following antibiotics were used: Ampicillin $(10 \mu \mathrm{g})$, Amoxicillin $(25 \mu \mathrm{g})$, nitrofurantoin $(300 \mu \mathrm{g})$, Cotrimoxazole $(1,25 / 3,75 \mu \mathrm{g})$, Nalidixique Acid $(30 \mu \mathrm{g})$, Erythromycin $(15 \mu \mathrm{g})$, Tetracycline $(30 \mu \mathrm{g})$, Streptomycin $(10 \mu \mathrm{g})$, Gentamicin $(15 \mu \mathrm{g})$, Thiamphenicol $(30 \mu \mathrm{g})$, Colistin $(50 \mu \mathrm{g})$, Penicillin $\mathrm{G}(6 \mu \mathrm{g})$. For each antibiotic, the diameter of the inhibition zone is measured and the bacteria's clinical category regarding each tested antibiotic (susceptible, intermediate, resistant) is determined.

\section{RESULTS}

The results of the bacteriological quality of the analyzed samples are presented in table 2 .

Table 1: Acceptability threshold required in minced meat according to local standards in Morocco and Luxemburg $[12,13]$.

\begin{tabular}{|c|c|c|c|c|c|}
\hline & $\begin{array}{c}\mathbf{T P C} \\
\times 10^{5} \\
\mathrm{CFU} / \mathrm{ml}\end{array}$ & $\begin{array}{c}\text { E. coli } \mathrm{x} \\
10^{2} \\
\mathrm{CFU} / \mathrm{ml}\end{array}$ & $\begin{array}{c}\text { S. Aureus X } \\
10^{2} \\
\text { CFU/ml }\end{array}$ & $\begin{array}{l}\text { Salmonella spp } \\
\text { in } 10 \mathrm{~g}\end{array}$ & $\begin{array}{c}\text { Listeria monocytogenes } \\
\text { in } 10 \mathrm{~g}\end{array}$ \\
\hline $\mathrm{m}$ & $\underline{5}$ & $\underline{1}$ & $\underline{1}$ & Absence & Absence \\
\hline $3 \mathrm{~m}$ & $\underline{15}$ & $\underline{3}$ & $\underline{3}$ & Absence & Absence \\
\hline M & $\overline{50}$ & $5 \times 10^{2}$ & $5 \times 10^{2}$ & $\overline{\text { Absence }}$ & $\overline{\text { Absence }}$ \\
\hline $\mathrm{m}$ & 5 & 0.5 & 5 & Absence & ב--- \\
\hline $3 \mathrm{~m}$ & 15 & 1.5 & 15 & Absence & --- \\
\hline $\mathrm{M}$ & 50 & 5 & 50 & Absence & ---- \\
\hline
\end{tabular}

TPC: total plate count; S. Aureus: Staphylococcus aureus, SRC: Sulfite Reducing bacteria growing under anaerobic conditions).

- The underlined values are the Moroccan standards

- The values written in bold are the European standards 
Kamal Belhaj et al., 2019. Antimicrobial resistance of pathogenic bacteria isolated from minced meat in Eastern Morocco/ American-Eurasian Journal of Sustainable Agriculture. 13(2): 34-40. DOI: 10.22587/aejsa.2019.13.2.3 
Kamal Belhaj et al., 2019. Antimicrobial resistance of pathogenic bacteria isolated from minced meat in Eastern Morocco/ American-Eurasian Journal of Sustainable Agriculture. 13(2): 34-40. DOI: 10.22587/aejsa.2019.13.2.3

Table 2: Charge (CFU/g) of microorganisms in ground beef collected in Oujda city Morocco

\begin{tabular}{|c|c|c|c|c|}
\hline & Min. & $\begin{array}{c}\text { Mean } \\
\text { Log (Mean) }\end{array}$ & Max. & Criteria (m) \\
\hline E. coli & $4.2 \times 10^{2}$ & $\begin{array}{c}\mathbf{1 . 5 \times 1 0 ^ { 4 }} \\
(4.17)\end{array}$ & $7.3 \times 10^{4}$ & $1 \times 10^{2}$ \\
\hline S. aureus & $<10$ & $\begin{array}{c}\mathbf{4 . 1 \times 1 0} \\
(3.61)\end{array}$ & $1.4 \times 10^{3}$ & $1 \times 10^{2}$ \\
\hline Salmonella spp. & \multicolumn{3}{|c|}{ presence } & Absence in $10 \mathrm{~g}$ \\
\hline
\end{tabular}

(Min. : minimal value, Max. : maximal value, Mean: mean value, E. coli; S. aureus: Staphylococcus aureus,

The results of the microbiological analysis of ground beef samples showed that $46.29 \%$ of samples are of satisfactory quality (below $3 \mathrm{~m}$ ), $18.51 \%$ are of acceptable quality (between $3 \mathrm{~m}$ and $\mathrm{M}$ ) and $35.18 \%$ are of unsatisfactory quality according to Moroccan and European standards (table 1). Salmonella spp is present in $13 \%$ of the analyzed samples.

The evaluation of minced meat's microbial quality was able to isolate 34 pathogenic bacteria, including 12 strains of E. coli, $12 \mathrm{~S}$. aureus, and seven salmonella spp to evaluate their antibiotic resistance. The study of susceptibility towards antibiotics was carried out using the diffusion in a solid medium method. Mueller-Hinton was the medium usedby the standards and the recommendations of the French society of microbiology's antibiogram committee [14]. The 12 most used antibiotics in animal and human therapy in Morocco were tested.

The results of antibiotic-resistance of bacteria isolates are presented in the table below

Table 3: Antibiotic-resistance of Escherichia coli, Salmonella spp. and Staphylococcus aureus strains isolated from minced meat in Eastern Morocco

\begin{tabular}{|c|c|c|c|c|c|c|c|c|c|c|c|}
\hline \multirow{2}{*}{ Antibiotic } & \multicolumn{3}{|c|}{ E. $\operatorname{coli}(\%)$} & \multicolumn{3}{|c|}{ Salmonella spp. (\%) } & \multicolumn{3}{|c|}{ S. aureus $(\%)$} & \multicolumn{2}{|c|}{ Criteria $(\mathbf{m m})$} \\
\hline & $\mathbf{R}$ & I & $\mathbf{S}$ & $\mathbf{R}$ & I & $\mathbf{S}$ & $\mathbf{R}$ & I & $\mathbf{S}$ & $\mathbf{S}$ & $\mathbf{R}$ \\
\hline Ampicillin & 100 & 0 & 0 & 100 & 0 & 0 & - & - & - & $\geq 14$ & $<14$ \\
\hline Amoxicillin & 100 & 0 & 0 & 87.5 & 12.5 & 0 & 71.42 & 28.57 & 0 & $\geq 21$ & $<16$ \\
\hline Nitrofurantoin & 85.71 & 0 & 14.28 & 100 & - & 0 & 100 & 0 & 0 & $\geq 11$ & $<11$ \\
\hline Co-trimoxazole & 0 & 0 & 100 & 33.33 & 66.66 & 0 & 0 & 0 & 100 & $\geq 16$ & $<13$ \\
\hline Nalidixic acid & 28.58 & 0 & 71.42 & 100 & 0 & 0 & - & - & - & $\geq 19$ & $<14$ \\
\hline Erythromycin & 100 & 0 & 0 & 100 & 0 & 0 & 50 & 0 & 50 & $\geq 22$ & $<17$ \\
\hline Tetracycline & 75 & 0 & 25 & 100 & 0 & 0 & 75 & 0 & 25 & $\geq 19$ & $<17$ \\
\hline Streptomycin & 57.14 & 0 & 42.85 & 83.33 & 0 & 16.66 & 14.28 & 0 & 85.71 & $\geq 15$ & $<13$ \\
\hline Gentamycin & 0 & 0 & 100 & 0 & 0 & 100 & 0 & 0 & 100 & $\geq 18$ & $<16$ \\
\hline Thiamphenicol & 100 & 0 & 0 & 100 & 0 & 0 & 100 & 0 & 0 & $\geq 23$ & $<23$ \\
\hline Colistin & 0 & 0 & 100 & 0 & 0 & 100 & 100 & 0 & 0 & $\geq 15$ & $<15$ \\
\hline Penicillin G & - & - & - & - & - & - & 57.14 & 0 & 42.85 & $\geq 26$ & $<26$ \\
\hline
\end{tabular}

S: Higher critical diameter; R: Lower critical diameter; R: Resistant; I: intermediate; S; sensitive

Inhibition Zones less than the indicated value $(\mathrm{R})$ indicate the bacterial strain was resistant.

\section{Escherichia coli}

According to the table above, the majority of the tested E. coli strands is resistant to antibiotics. $100 \%$ of tested E. coli strands are resistant to penicillin A family (Amoxicillin, Ampicillin), Erythromycin and Thiamphenicol. However, all tested $E$. coli strands have shown a susceptibility to Co-trimoxazole, Gentamicin, and Colistin. Concerning Nitrofurantoin, Tetracycline, Streptomycin, and Nalidixic acid, the tested E. coli strands have shown a resistance to these antibiotics with percentages varying between $85.71 \%, 75 \%, 57.14 \%$ and $28.58 \%$ respectively.

\section{Salmonella spp}

According to table 3, $100 \%$ of the studied Salmonella isolates are resistant to Ampicillin, Amoxicillin, Nalidixic Acid, Erythromycin and Tetracycline. $83.33 \%$ of salmonella spp have shown a resistance to Streptomycin. However, $100 \%$ of the isolates have shown a susceptibility to Gentamicin and $66.66 \%$ are intermediate to Co-trimoxazole 
Kamal Belhaj et al., 2019. Antimicrobial resistance of pathogenic bacteria isolated from minced meat in Eastern Morocco/ American-Eurasian Journal of Sustainable Agriculture. 13(2): 34-40. DOI: 10.22587/aejsa.2019.13.2.3

Table 4: Comparative study of E. coli antibiotic resistance of analyses carried out in Morocco, Algeria, Senegal, Madagascar and Vietnam

\section{Staphylococcus aureus}

The results show that $100 \%$ of $S$. aureus isolates are resistant to Nitrofurantoin, Thiamphenicol and colistin.71.42\%, $75 \%$ and $57.14 \%$ are resistant to Amoxicillin, Tetracycline and Penicillin G respectively. However, $100 \%$ of $S$. aureus isolates are susceptible to Co-trimoxazole and Gentamicin, $85.71 \%$ are susceptible to Streptomycin and 50\% are susceptible to Erythromycin. All the tested bacterial strands have shown a resistance to multiple antibiotics at once ( 8 antibiotics or less). It's a case of multi-drug resistance.

\section{DISCUSSION}

Widespread antibiotic resistance is a serious threat to the global population. This problem exists everywhere, especially in third world countries due to self-medication.

According to our investigation, almost all tested E. coli strands are highly resistant to Penicillin, Tetracycline, Nitrofurantoin, and Phenicol. The obtained results are higher than those previously reported in Morocco and elsewhere (table 4). These percentages have increased throughout the years; it is a development of antibiotic resistance [15-18]. However, resistance to Gentamicin and Colistin has decreased, this result can be explained on the on hand by, the fact that they're the first ones to be forbidden by Moroccan law since 2001 and on the other hand by, their effect on bacteria (action mechanism) makes it difficult for them to develop a resistance. The results of resistance to Penicillin A, Tetracycline and Phenicol are higher than those reported by Meng, Zhao [19] the USA, Diouf [20] in Senegal, Van, Chin [21] in Vietnam, Benameur, Glamour [22] in Algeria and Ravaonindrina, Razanajatovo [23] in Madagascar.

Moreover, our results show that the tested Salmonella strains are multi-resistant to antibiotics. This result is disturbing in the case of phenicols and Nitrofurantoin since the former is considered carcinogenic, and the latter causes cardiac degenerescence or nervous diseases in poultry [24]. As for aminoglycosides, the studied salmonella spp strains are susceptible to Gentamicin, and $83.33 \%$ of them are resistant to Streptomycin. Our results are higher than those reported by Fofana [25] and Diouf [20] in Senegal and Ravaonindrina, Razanajatovo [23] in Madagascar (table 5). Our results are by the World Health Organization's announcement about multi-resistant salmonella strains to Ampicillin, Chloramphenicol, Streptomycin, Sulfonamides and Tetracycline (table 4, 5 and 6).

The $S$. aureus bacteria used in this research are resistant to multiple antibiotics (Nitrofurantoin, Penicillin A, Thiamphenicol, and Colistin). The high resistance of $S$. aureus to the formerly mentioned antibiotics and susceptibility to Nitrofurantoin and Co-trimoxazole is because the former ones have replaced the latter ones considering the developed antibiotic-resistance [26, 27]. Similar results were reported by Hanson, Dressler [28] about $S$. aureus isolated from meat sold at retail in Austria. Furthermore, our results are lower than those reported by Achi and Madubuike [29] in Nigeria. However, they are higher than those found by Aydin, Muratoglu [30] in turkey (table 6).

This high rate of antibiotic resistance is mainly due to self-medication, as well as the use of broad-spectrum antibiotics, which cause the development of direct and indirect antibiotic resistance. The excessive and unreasonable use of antibiotics on farms contributes to the modification of bacterial resistance. Enterobacteriaceae can pass on their resistance genes to pathogenic bacteria that become refractory to conventional treatments despite being commensally flora [31]. Human contamination or infection by microbial resistant bacteria can have serious health consequences. Thus, monitoring and controlling antibiotic resistance remains a vital tool to preserve public health. 
Kamal Belhaj et al., 2019. Antimicrobial resistance of pathogenic bacteria isolated from minced meat in Eastern Morocco/ American-Eurasian Journal of Sustainable Agriculture. 13(2): 34-40. DOI: 10.22587/aejsa.2019.13.2.3

\begin{tabular}{|c|c|c|c|c|c|c|c|c|c|c|c|c|}
\hline \multirow[b]{2}{*}{ Antibiotic } & \multirow[b]{2}{*}{$\begin{array}{c}\text { Our } \\
\text { study }\end{array}$} & \multirow[b]{2}{*}{$\begin{array}{c}{[15]} \\
\text { in } \\
\mathbf{M A}\end{array}$} & \multicolumn{2}{|c|}{ [16] in MA } & \multirow[b]{2}{*}{$\begin{array}{c}{[18]} \\
\text { in } \\
\text { MA }\end{array}$} & \multirow[b]{2}{*}{$\begin{array}{c}{[32]} \\
\text { in } \\
\text { MA }\end{array}$} & \multirow[b]{2}{*}{$\begin{array}{c}{[33]} \\
\text { in } \\
\text { BEN }\end{array}$} & \multirow{2}{*}{$\begin{array}{c}{[22]} \\
\text { in } \\
\mathbf{D Z}\end{array}$} & \multirow[b]{2}{*}{$\begin{array}{c}{[21]} \\
\text { In } \\
\text { VN }\end{array}$} & \multirow[b]{2}{*}{$\begin{array}{c}{[25]} \\
\text { in } \mathbf{S N}\end{array}$} & \multirow[b]{2}{*}{$\begin{array}{c}{[20]} \\
\text { In SN }\end{array}$} & \multirow[b]{2}{*}{$\begin{array}{c}{[23]} \\
\text { in } \\
\text { MDG }\end{array}$} \\
\hline & & & $\begin{array}{l}1985 \\
- \\
1986\end{array}$ & $\begin{array}{l}1991 \\
- \\
1992\end{array}$ & & & & & & & & \\
\hline A 10 & 100 & 20 & 20 & 14 & 75.4 & - & 87.77 & - & 50.5 & 55.56 & 41.61 & - \\
\hline A 25 & 100 & - & ND & ND & - & 90.1 & - & - & 50.5 & - & - & 22.80 \\
\hline N 300 & 85.71 & - & 64 & 1 & - & - & - & - & - & - & - & - \\
\hline Cot 5 & 0 & 8 & 8 & 61 & 68.3 & - & 58.99 & 70.2 & 51.5 & 73.33 & 90.76 & - \\
\hline Na 30 & 28.58 & - & 4 & 25 & - & - & 41.73 & - & 34.3 & 54.44 & 50.75 & 0 \\
\hline E 15 & 100 & - & - & - & - & - & - & - & - & - & & - \\
\hline T 30 & 75 & 82 & 82 & 65 & - & 100 & - & 90.4 & 77.8 & 88.89 & 90.76 & - \\
\hline S 10 & 57.14 & - & 44 & 32 & - & - & - & - & 39.4 & 56.67 & 52.3 & - \\
\hline G 15 & 0 & 0 & 0 & 7 & 25 & - & 1.44 & - & 24.2 & 3.33 & - & 0 \\
\hline T 30 & 100 & 42 & 42 & 41 & - & - & 30.94 & - & 43.4 & - & 6.15 & 17.5 \\
\hline C 50 & 0 & 0 & 0 & 0.4 & 3.3 & 2.9 & - & 31.6 & - & - & - & 7 \\
\hline
\end{tabular}

Comparative study of $E$. coli antibiotic resistance of analyses carried out in Morocco (MA), Algeria (DZ), Senegal $(\mathrm{SN})$, Madagascar (MDG) and Vietnam (VN)

A10: Ampicillin $(10 \mu \mathrm{g})$; A25: Amoxicillin $(25 \mu \mathrm{g})$; N 300: nitrofurantoin $(300 \mu \mathrm{g})$; Cot 5: Co-trimoxazole $(1,25 / 3,75 \mu \mathrm{g})$ : $\mathrm{Na}$ 30: Nalidixique Acid $(30 \mu \mathrm{g})$; E 15: Erythromycin $(15 \mu \mathrm{g})$; $\mathrm{T}$ 30: Tetracycline $(30 \mu \mathrm{g})$; S 10 :

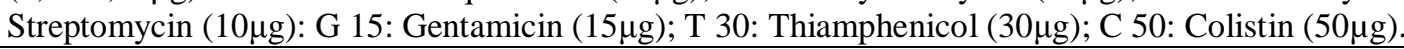

Table 5: Comparative study of different Salmonella spp antibiotic resistance analyses

\begin{tabular}{|c|c|c|c|c|}
\hline Antibiotic & Our study & $\begin{array}{c}{[25]} \\
\text { in Senegal }\end{array}$ & $\begin{array}{c}{[20]} \\
\text { in Senegal }\end{array}$ & $\begin{array}{c}{[23]} \\
\text { in Madagascar }\end{array}$ \\
\hline Ampicillin & 100 & 35.48 & 53.52 & - \\
\hline Amoxicillin & 87.5 & - & - & 2.7 \\
\hline Nitrofurantoin & 100 & - & - & - \\
\hline Co-trimoxazole & 33.33 & 36.56 & 64.78 & - \\
\hline Nalidixic Acid & 100 & - & - & - \\
\hline Erythromycin & 100 & - & - & - \\
\hline Tetracycline & 100 & 46.24 & 73.24 & - \\
\hline Streptomycin & 83.33 & - & - & 0 \\
\hline Gentamycin & 0 & - & - & 10 \\
\hline Thiamphenicol & 100 & - & - & 0 \\
\hline Colistin & 0 & - & - & - \\
\hline
\end{tabular}

Table 6: Comparative study of different $S$. aureus antibiotic resistance analyses

\begin{tabular}{|c|c|c|c|c|}
\hline Antibiotic & Our study & {$[29]$ in Nigeria } & {$[28]$ in Austria } & {$[30]$ in Turkey } \\
\hline Ampicillin & - & - & - & - \\
\hline Amoxicillin & 71.42 & 42 & - & - \\
\hline Nitrofurantoin & 100 & - & - & 13 \\
\hline Co-trimoxazole & 0 & 4.2 & 0 & - \\
\hline Nalidixic Acid & - & - & - & 18.2 \\
\hline Erythromycin & 50 & 4.2 & 14.8 & 15.6 \\
\hline Tetracycline & 75 & 70 & 66.7 & 6.5 \\
\hline Streptomycin & 14.28 & 75 & & 15.6 \\
\hline Gentamycin & 0 & 70.8 & 0 & - \\
\hline Thiamphenicol & 100 & 0 & - & 71.4 \\
\hline Colistin & 100 & - & - & 77.7 \\
\hline Penicillin G & 57.14 & - & & \\
\hline
\end{tabular}


Kamal Belhaj et al., 2019. Antimicrobial resistance of pathogenic bacteria isolated from minced meat in Eastern Morocco/ American-Eurasian Journal of Sustainable Agriculture. 13(2): 34-40. DOI: 10.22587/aejsa.2019.13.2.3

\section{CONCLUSION}

This study has revealed that minced meat sold in eastern Morocco is contaminated with pathogenic bacteria such as E. coli and salmonella spp. These results are mainly due to poor hygiene conditions found throughout the production chain. Antibiotic resistance is a global concern due to its health and economic impacts. It can touch anyone, regardless of his/her age or location. The consequences of antibiotic resistance include reducing the available choices of antibiotics for the treatment of bacterial infections or even a limitation to a single class of antibiotics. In some extreme cases, no antibiotic has any effect. The increase of antibiotic resistance over the years is due to the irrational and/or excessive use of antibiotics. Thus, the best way to reduce the selective pressure of antibiotics on bacteria is to reduce their use. In veterinary medicine, a measure of this kind has been the prohibition of a few antimicrobial drugs in order to decrease this issue. This study remains a first step, as part of raising public awareness about antibiotic-resistance and the risks caused by this crucial issue.

\section{ACKNOWLEDGEMENTS}

We are grateful to the National Office for Food Safety (ONSSA, Direction régionale de l'oriental du Maroc), particularly to the regional Laboratory of Analysis and Research.

\section{REFERENCES}

[1] Pomba, C., Rantala M., Greko C., Baptiste K.E., Catry B., Van Duijkeren E., Mateus A., Moreno M.A., Pyörälä S., and Ružauskas M., (2016) Public health risk of antimicrobial resistance transfer from companion animals. J Antimicrob Chemoth. 72(4): p. 957-968.

[2] Marques, C., Belas A., Franco A., Aboim C., Gama L.T., and Pomba C., (2017) Increase in antimicrobial resistance and emergence of major international high-risk clonal lineages in dogs and cats with urinary tract infection: 16 year retrospective study. J Antimicrob Chemoth. 73(2): p. 377-384.

[3] Vitale, M., Gaglio S., Galluzzo P., Cascone G., Piraino C., Di Marco Lo Presti V., and Alduina R., (2018) Antibiotic resistance profiling, analysis of virulence aspects and molecular genotyping of Staphylococcus aureus isolated in Sicily, Italy. Foodborne Pathog Dis. 15(3): p. 177-185.

[4] Omulo, S., Thumbi S.M., Njenga M.K., and Call D.R., (2015) A review of 40 years of enteric antimicrobial resistance research in Eastern Africa: what can be done better? Antimicrob Resist In. 4(1): p. 1.

[5] Fair, R.J.and Tor Y., (2014) Antibiotics and bacterial resistance in the 21st century. P PMC. 6: p. S14459.

[6] Tanwar, J., Das S., Fatima Z., and Hameed S., (2014) Multidrug resistance: an emerging crisis. Interdiscip Perspect Infect Dis. 2014.

[7] Van Den Honert, M., Gouws P., and Hoffman L., (2018) Importance and implications of antibiotic resistance development in livestock and wildlife farming in South Africa: A Review. Interdiscip Perspect Infect Dis. 48(3): p. 401-412.

[8] HCP. Le Maroc en chiffre 2017; Available from: file://C:/Users/lenovo/Downloads/Le\%20Maroc\%20en\%20chiffres,\%202017\%20(version\%20arabe\% 20\&\%20fran\%C3\%A7aise).pdf.

[9] ISO, (1999) 6888, Microbiology of Food and Animal Feeding Stuffs-Horizontal Method for the Enumeration of Coagulase-Positive Staphylococci (Staphylococcus aureus and Other Species). Part 1. Technique Using Baird-Parker Agar Medium. Brussels: European Committee for Standardization.

[10]ISO, Microbiology of food and animal feeding stuffs - Horizontal method for the enumeration of glucuronidase-positive Escherichia coli. 2001, International Organization for Standardization Geneva.

[11]ISO, Microbiology of food and animal feeding stuffs -Horizontal method for the detection of Salmonella spp (ISO 6579: 2002). 2002, International Organization for Standardization: Geneva.

[12] SGGM, S.g.d.g.M., (2004) Arrêté conjoint du ministre de l'agriculture et du développement rural, du ministre de la santé et du ministre de l'industrie, du commerce et des télécommunications n ${ }^{\circ} 624-04 \mathrm{du}$ 17 safar 1425 (8 avril 2004) relatif aux normes microbiologiques auxquelles doivent répondre les denrées animales ou d'origine animale. Bulletin officiel du gouvernement Marocaine. 5214 p. 727-752.

[13] Health, d., Critères microbiologiques applicables aux denrées alimentaires Lignes directrices pour l'interprétation. 2015, Gouvernement du grand-duché de Luxembourg Luxembourg p. 57.

[14] Bonnet, R., Caron F., Cavallo J., Chardon H., Chidiac C., Courvalin P., Drugeon H., Dubreuil L., Jarlier V., and Jehl F., Comité de l'Antibiogramme de la Société Française de Microbiologie, in Recommandations. 2013.

[15] Filali, E., Bell J., El Houadfi M., Huggins M., and Cook J., (1988) Antibiotic resistance of Escherichia coli strains isolated from chickens with colisepticaemia in Morocco. CIMID. 11(2): p. 121-124. 
Kamal Belhaj et al., 2019. Antimicrobial resistance of pathogenic bacteria isolated from minced meat in Eastern Morocco/ American-Eurasian Journal of Sustainable Agriculture. 13(2): 34-40. DOI: 10.22587/aejsa.2019.13.2.3

[16] Amara, A., Ziani Z., and Bouzoubaa K., (1995) Antibioresistance of Escherichia coli strains isolated in Morocco from chickens with colibacillosis. Vet Microbiol. 43(4): p. 325-330.

[17] Hafed, Z., Benguedour R., Aboussaleh Y., zeghari L., Aouane M., Berrid N., Abouchouaib N., and Sbaibi R., (2014) profil d'antibioresistance d'escherichia coli d'origine aviaire: cas de poulet de chair dans la region de grande casablanca. Am. J. innov. res. appl. sci. 2(2): p. 50-54.

[18] Huiting, J., Antimicrobial resistance of Escherichia coli in broilers with colibacillosis in Morocco. 2015.

[19] Meng, J., Zhao S., Doyle M.P., and Joseph S.W., (1998) Antibiotic resistance of Escherichia coli O157: H7 and O157: NM isolated from animals, food, and humans. Food Protect. 61(11): p. 1511-1514.

[20]Diouf, K. 2006. Surveillance de la résistance aux antibiotiques des souches de Salmonella spp. et Escherichia coli isolées de la viande de poulet de chair au Sénégal. Mémoire de DEA, EISMV, Dakar. Doctorat, EISMV.

[21] Van, T.T.H., Chin J., Chapman T., Tran L.T., and Coloe P.J., (2008) Safety of raw meat and shellfish in Vietnam: an analysis of Escherichia coli isolations for antibiotic resistance and virulence genes. Int $\mathrm{J}$ Food Microbiol. 124(3): p. 217-223.

[22] Benameur, Q., Guemour D., Hammoudi A., Aoudia H., Aggad H., Humblet M., and Saegerman C., (2014) Antimicrobial resistance of Escherichia coli isolated from chickens in West of Algeria. IJSBAR. 13(1): p. 366-370.

[23] Ravaonindrina, N., Razanajatovo I., and Bastaraud A., (2015) Qualité microbiologique de la viande commercialisée dans la communauté urbaine d'Antananarivo. Rev Elev Med Vet Pays Trop. 67(3): p. 122-123.

[24] Fontaine, M. and J. L. Adole 1995. Vade mecum du vétérinaire.France.

[25] Fofana, A. 2004. Etude de la résistance aux antibiotiques des souches de Salmonella (spp) et de Escheichia coli isolées de la viande des poulets de chair au Sénégal. Doctorat, EISMV/UCAD

[26] Garau, J., (2008) Other antimicrobials of interest in the era of extended-spectrum $\beta$-lactamases: Fosfomycin, nitrofurantoin and tigecycline. Clin Microbiol Infec. 14(s1): p. 198-202.

[27] McKinnell, J.A., Stollenwerk N.S., Jung C.W., and Miller L.G. Nitrofurantoin compares favorably to recommended agents as empirical treatment of uncomplicated urinary tract infections in a decision and cost analysis. in Mayo Clinic Proceedings. 2011. Elsevier.

[28] Hanson, B., Dressler A., Harper A., Scheibel R., Wardyn S., Roberts L., Kroeger J., and Smith T., (2011) Prevalence of Staphylococcus aureus and methicillin-resistant Staphylococcus aureus (MRSA) on retail meat in Iowa. J Infect Public Heal. 4(4): p. 169-174.

[29] Achi, O.and Madubuike C., (2007) Prevalence and antimicrobial resistance of Staphylococcus aureus isolated from retail ready-to-eat foods in Nigeria. Res J Microbiol. 2(6): p. 516-523.

[30] Aydin, A., Muratoglu K., Sudagidan M., Bostan K., Okuklu B., and Harsa S., (2011) Prevalence and antibiotic resistance of foodborne Staphylococcus aureus isolates in Turkey. Foodborne Pathog Dis. 8(1): p. 63-69.

[31] Landers, T.F., Cohen B., Wittum T.E., and Larson E.L., (2012) A review of antibiotic use in food animals: perspective, policy, and potential. Public Health Rep. 127(1): p. 4-22.

[32] Rahmatallah, N., Nassik S., El rhaffouli H., Lahlou Amine I., and El houadfi M., (2016) Détection de souches multi-résistantes d'Escherichia coli d'origine aviaire dans la région de Rabat Salé Zemmour Zaer. Revue Marocaine des Sciences Agronomiques et Vétérinaires. 5(2).

[33] Ahouandjinou, H., Baba-Moussa F., Bertin G., Sina H., Adéoti K., Mousse W., Pouadjeu-Wouansi S., Toukourou F., Soumanou M., and Baba-Moussa L., (2016) Antibiorésistance Et Facteurs De Virulence Des Souches D’escherichia Coli Isolées Des Carcasses Bovines Du Bénin, ESJ. 12(33). 